\title{
Erdal Marcel, Nevskaya Irina, Nugteren Hans, Rind- Pawlowski Monika (Hg.), Handbuch des \\ Tschalkantürkischen
}

Teil 1 : Texte und Glossar, Harrassowitz Verlag, Wiesbaden, 2013. xii, 252

S (Turcologica, Bd. 91,1), ISBN 978-3-447-06964-9

Dmitri Funk, Oksana Poustogacheva et Irina Popravko

\section{OpenEdition}

\section{Journals}

Édition électronique

URL : https://journals.openedition.org/emscat/2700

DOI : $10.4000 /$ emscat.2700

ISSN : 2101-0013

Éditeur

Centre d'Etudes Mongoles \& Sibériennes / École Pratique des Hautes Études

Référence électronique

Dmitri Funk, Oksana Poustogacheva et Irina Popravko, « Erdal Marcel, Nevskaya Irina, Nugteren Hans, Rind-Pawlowski Monika (Hg.), Handbuch des Tschalkantürkischen », Études mongoles et sibériennes, centrasiatiques et tibétaines [En ligne], 46 | 2015, mis en ligne le 10 septembre 2015, consulté le 13 juillet 2021. URL : http://journals.openedition.org/emscat/2700 ; DOI : https://doi.org/10.4000/ emscat. 2700

Ce document a été généré automatiquement le 13 juillet 2021.

(c) Tous droits réservés 


\section{Erdal Marcel, Nevskaya Irina, Nugteren Hans, Rind-Pawlowski Monika (Hg.), Handbuch des Tschalkantürkischen}

Teil 1 : Texte und Glossar, Harrassowitz Verlag, Wiesbaden, 2013. xii, 252

S (Turcologica, Bd. 91,1), ISBN 978-3-447-06964-9

Dmitri Funk, Oksana Poustogacheva et Irina Popravko

\section{RÉFÉRENCE}

Erdal Marcel, Nevskaya Irina, Nugteren Hans, Rind-Pawlowski Monika (Hg.) Handbuch des Tschalkantürkischen, Teil 1 : Texte und Glossar. Harrassowitz Verlag, Wiesbaden, 2013. xii, 252 S (Turcologica, Bd. 91,1)

\section{NOTE DE L'AUTEUR}

Written in the framework of the project "Man in a Changing World. Problems of Identity and Social Adaptation in History and at Present" (the RF Government grant No. 14.B25.31.0009)

Chelkans ${ }^{1}$ - or, as they are usually called by linguists and native folklorists, Chalkans are amongst the smallest of the Turkic groups of the indigenous population of Siberia. Practically throughout the whole Soviet period of history they were known as "an ethnic group" of the (northern) Altai people. Chelkans, as a matter of fact, have not become an object of serious interest either for linguists or for social anthropologists, in spite of the relatively isolated location and longstanding conservation of many features 
of their traditional culture, including folklore and language. One would think that this should be ample reason to rouse the interest of researchers.

2 All the research into certain features of their language and culture, which shows a gradual increase since the middle of the 1970s, was based solely on material collected during short-term expeditionary trips. Nevertheless, there are just a few monographic works dedicated to the Chelkans, which is why every publication on this topic deserves special attention.

3 Handbuch des Tschalkantürkischen, edited by Marcel Erdal, Irina Nevskaya, Hans Nugteren and Monika Rind-Pawlowski, is the first part of a monographic description of Chelkan language planned by the considerably large team of authors. ${ }^{2}$ The work has the subtitle "Texts and glossary", which by itself covers three quarters of the content (pp.1-185), although in fact such issues as Chelkan ethnography, lexicology and ethnomusicology are also touched upon (chapter 3, pp.189-252). All this makes the publication a matter of considerable for a wide circle of specialists.

4 The editors of the book highlight the fact that the Chelkan language - features of which reveal a strong resemblance to Shor, Khakas and Chulym-Turkic languages rather than to Altai - is part of a language continuum, and cannot therefore be included into any of its neighboring languages (p. viii). Such an approach to the Chelkan language can only be welcomed.

5 In the introduction the authors characterize the available material. As far as it can be judged by the description, it is exceedingly broad and covers notes collected between 1950 and 2005 : materials of colleagues from the Institute of Philology in Novosibirsk from 2000 till 2001 (p. viii), materials from the personal archive of A. Kandarakova from 1950 till 1970 (p. ix) and 25 pages of text material forwarded to the authors by their Turkish colleague Figen Güner Dilek (p. xi). However the majority of the texts in this volume have been taken specifically from the archive of Kandarakova (p. xii), whose identity and role as a researcher receive no further mention in the text.

6 There is apparently also personal field material collected by the authors, but it is hard to form an opinion about this: there is little detailed informaton about the years during which the "Chalkan project" (financed by the DFG and the RFBR ${ }^{3}$ ) was carried out. The project was, however, obviously very productive. The evidence for this is not only the book under review, but also 23 long and short articles, published within the frameork of the project, as well as two brochures containing examples of the folklore (see the list on pages ix-xi). The majority of the articles were included in two "Chalkan collected volumes", from the series "The languages of the indigenous people of Siberia" (published in Novosibirsk in 2004 and 2005).

7 The first chapter - "Chalkan texts" ("Tschalkanische Texte", pp. 1-105) - includes a fairytale, a legend, a funny short story, a description of leather working and five recipes for traditional dishes. It also contains 66 "proverbs/sayings" and 59 riddles. All the published texts are written in the Chelkan language in Cyrillic, glossed and provided with translations into Russian and German. A large number of the texts are published here for the first time, although some of them were obviously known much earlier, as they had been published in the book Altaiskii fol'klor a quarter of a century ago (1988). We have collated the first 18 riddles, of which seven were published in different variants in the aforementioned volume Altaiskii fol'klor. 
There is also a lack of commentary : both the riddles and proverbs ${ }^{4}$ of Chelkans are rich with traditional figurativeness. This can cause confusion with regard to their meaning for anyone insufficiently familiar with the ethnography of the Turkic groups of the Sayan-Altai region. In publications of material of this sort it seems advisable to provide an example of every minor genre not only with lemma and translation, but also with variants and explanation of the meaning of an expression, characteristics of the cultural context and biographical information about the narrators (for an exemplary presentation, see Shongolo \& Schlee 2007).

In the vast majority of cases, translations (especially into German ${ }^{5}$ ) are of high quality ; this in spite of the fact that the terminology connected with traditional culture was undoubtedly difficult to understand for the authors of the book. In the fairytale "Arabushka" (Arabušqa) (pp. 3-42) for instance, one can find Chelkan terms like toon and para. The first is translated as « МоРдА» (a fish trap; Germ. Korbgeflecht zum Fischfang), the second as «СЕTЬ» (a fishing-net; Germ. Fischernetz) (sentence 5) or as «НЕВОД» (a seine ; Fischernetz) (sentence 7) (p.4). The term toon in fact means «ЗАЕЗДОК»/« ЗАЕЗДКА» (a fish weir), or - more commonly - «ЗАПОР» (a special hedge used for fishing), and is not related to the terms « МОРДА» оr « МОРДУШКА» (а fish trap). Para is not a seine, but a fishing-net of which one part is in the form of a cone. It was often used as an element of a special hedge for fishing (toon), but apparently it could also be used separately. An example of this can be found in the culture of Shors (see Funk 1996, pp. 258-259; for more details see Bel'gibaev 2004, pp. 52-55).

Chapter 2 provides a Chelkan-German-Russian glossary ("Glossar TschalkanischDeutsch-Russisch", pp. 107-185). It covers not only the texts published in this book, but the whole textual corpus (i.e. folklore texts and words to be found in the articles which will be discussed later) created by the authors, of which this publication contains only a part. Being aware of the fact that these word forms originate from different sources and were fixed in different variants of pronunciation, the compilers of the glossary deserve credit: they have intentionally avoided homogenization, and have faithfully recorded every variant registered in their corpus.

11 Altogether, the glossary comprises approximately 1500 dictionary entries, and is currently one of the most voluminous, or perhaps even the most voluminous, dictionary of the Chelkan language. There is, however, scope for a multiple expansion of the dictionary: first, by adapting the texts that have been published in several collected volumes of folklore which were beyond the authors' reach; secondly, by analysing the folklore archive of the Institute of Altaistics in the city of Gorno-Altaisk, where multiple notes on Chelkan can be found ; and thirdly, by more active and longterm work directly with Chelkan speakers.

The book finishes with articles and materials in English and German language subsumed in third chapter under the general title "Ethnological and lexicological research” („Ethnologische und lexikologische Untersuchungen“, pp. 187-252). Amongst them are a review article by E. Belgibaev, "Ethnic-historical data about the Chalkans", pp. 189-199, articles dedicated to particular aspects of Chelkan folklore (particularly to so-called "short songs"), "Model tunes of the 'short songs' of the Chalkans" by G. B. Syčenko, pp. 201-206, and to the Chelkan lexicon - "Kinship terms in the Chalkan language" ("Verwandschaftstermini im Tschalkanischen") by E. Tjunteševa and O. Šagdurova (pp. 207-229), and "Some denominations of insects in Chelkan language 
(in comparison with the other Southern Siberian Turkic languages)" ("Einige Insektennamen $\mathrm{im}$ Tschalkanischen [im Vergleich $\mathrm{zu}$ anderen südsibirischen Türksprachen]") by M. V. Sumačakova, O. Ju. Šagdurova \& H. Nugteren, pp. 231-246.

The majority of the articles contribute something new to our understanding of Chelkan language and culture. Only the article about kinship terms is somewhat disappointing, as this text was already published in Russian 11 years ago by the same authors (Nikolina, Kokoshnikova 2004). ${ }^{6}$ We may also conclude that, on the one hand, from the perspective of knowledge about the regional literature (particularly about Chelkans), and on the other hand from the perspective of familiarity with general theoretical problems of this social phenomenon, this article was unfortunately written without reference to the anthropological discourse on kinship systems. As the bibliography of the article shows, the authors were not aware of the early works of Leonid P. Potapov where the abovementioned system was characterized and provisionally analyzed for the first time (see, e.g. Potapov 1937, pp. 5-6). Without this background it is difficult to understand what led this system, with its 29 terms (which in 1936 were the only ones to denote 679 possible variants of kinship categories $\left.{ }^{7}\right)$, to those 40 terms that were discovered by the authors of the article.

At the end of the Chelkan volume there are three lists: a list of male and female Chelkan names (pp. 247-248), a list of Chelkan surnames and "tribal names" (Stammesnamen, p. 248), and a Chelkan bibliography (pp. 249-252).

While the first two lists might admittedly be interesting for native Chelkans, they are hardly useful for specialists: none of the lists mentions the author, the source of information, or the time when a given item of data was gathered. While speaking about lists of names, it is obvious that proper names can be found in the archives, or collected from informants in the field, or found in genealogies or (other) folklore texts. Moreover, the folklore texts can be simple everyday stories or hero epics - the difference is considerable. A similar remark can be made with regard to clan structure, for it cannot be taken as a given fact : clan structure is full of dynamism and is reflected on differently from case to case in the consciousness of a certain informant. Furthermore, it is expressed differently from one situation to another.

While reading the book many remarks and thoughts arise; however it must be emphasized that, generally speaking, the work leaves a generally positive impression. As mentioned above, there are only a few academic works dedicated to Chelkans, ${ }^{8}$ especially in German and English. This alone is enough for the book to be acknowledged as a considerable contribution to the development of Turcology. However this is not the only feature in its favour: the collective work Handbuch des Tschalkantürkischen offers new and interesting material both to linguists and to folklorists, and what is even more valuable is that it makes one reflect while reading. That, in general, can be considered one of the most important qualities of any scientific work. 


\section{BIBLIOGRAPHIE}

Shongolo, A. A., Schlee, G.

2007 Boran Proverbs in their Cultral Context [Köln, Rüdiger Köppe Verlag] (Wortkunst und

Dokumentartexte in afrikanischen Sprachen, Bd.24).

Altaiskii fol'klor

1988 Altaiskii fol'klor (Materialy po chalkanskomu dialektu). Zapis', sostavlenie i perevod E.P.

Kandarakovoi (Gorno-Altajsk, Gogno-Altaiskoe otdelenie Altaiskogo knizhnogo izdatel'stva).

Bel'gibaev, E. A.

2004 Traditsionnaia material'naia kul'tura chelkantsev bassejna $r$. Lebed' (vtoraia polovina XIX - XX v.)

(Barnaul, izd-vo Altaiskogo universiteta).

Nikolina, E. V., Kokoshnikova, O. Iu.

2004 Terminy rodstva v chalkanskom iazyke v sopostavlenii s tiurkskimi iazykami Iuzhnoj Sibiri, in Shirobokova N.N. (ed.) Iazyki korennyh narodov Sibiri. Vyp. 15 : Chalkanskij sbornik (Novosibirsk, NGU), pp. 33-54.

Potapov, L. P.

1937 Perezhitki rodovogo stroia u severnyh altaicev (po materialam ekspeditsii v Ojrotiiu $v 1936$ g.)

(Leningrad, Gosudarstvennyi muzei ètnografii).

Funk, D. A.

1996 Iz materialov ètnograficheskoi poezdki k chelkantsam v avguste 1990 g., in Funk D. A. (ed.)

Problemy ètnicheskoj istorii $i$ kul'tury tjurko-mongol'skih narodov Iuzhnoi Sibiri i sopredel'nyh territorii.

Vyp. 2 (Moskva, Institut ètnologii i antropologii RAN), pp. 242-265.

Funk, D. A. (ed.)

2000 Chelkantsy $v$ issledovaniiah i materialah XX veka (Moskva, Institut ètnologii i antropologii RAN).

Funk, D. A., Bel'gibaev, E. A., Dobzhanskaia, O. È.

2006 Čelkantsy, in Funk D. A., Tomilov N. A. (eds.), Tiurkskie narody Sibiri (Moskva, Nauka), pp. 463-490.

\section{NOTES}

1. Henceforth we will use this variant to render the ethnonym. The form is justified by ethnographic tradition, and by the fact that nowhere in the official documents of Russia (population census, lists of small peoples) is the nationality "Chalkans" mentioned. Since 2000 the Chelkans have been officially appointed indigenous peoples of the Russian Federation (RF Government Regulation №255 from 24.03.2000).

2. On the title page eight authors are named - M. Erdal, A. Ozonova, I. Nevskaya, M. RindPawlowski, H. Nugteren, E. Tjuntesheva, O. Shagdurova, A. Tazranova, and N. Shirobokova - but in fact certain parts of the book are written by other authors: E. Bel'gibaev (pp. 189-199), G. Syčenko (pp. 201-206) and M. Sumačakova (pp. 231-246).

3. Deutsche Forschungsgemeinschaft (DFG) / Russian Foundation for Basic Research (RFBR).

4. For the authors of the book Handbuch des Tschalkantürkischen this question was obviously not very important.

5. Unfortunately, translations into Russian language are at times stylistically rather weak, and it is sometimes doubtful that they were made by native speakers. 
6. In the annotation to this article and in the bibliographic lists in the present book this publication is not mentioned.

7. The questionnaire with which L.P. Potapov worked contained exactly this number of questions. What questionnaire was used by the authors of the present article is not mentioned in the book.

8. Of the recent extensive collective reviews, mention may be made of Funk 2000 and Funk, Bel'gibaev, Dobzhanskaia 2006. 